Article

\title{
Poverty Suburbanization: Theoretical Insights and Empirical Analyses
}

\author{
Kenya L. Covington \\ Department of Urban Studies and Planning, California State University, Northridge, 18111 Nordhoff Street, Northridge, \\ CA 91330, USA; E-Mail: kcovington@csun.edu; Tel: +1-818-677-6463; Fax: +1-818-677-5850
}

Submitted: 11 June 2014| In Revised Form: 11 September 2014 | Accepted: 22 October 2014 |

Published: 9 April 2015

\begin{abstract}
Today almost every major metropolitan area in the U.S. has experienced rising poverty at a rate that surpasses its urban core (Kneebone \& Berube, 2013, p. 2). Poverty suburbanization has accelerated about 3.3 percentage points over the last decade. In this article, factors associated with the growing share of poor in suburbs in the 100 largest metropolitan areas were examined. The analysis sought to address the overarching question: what metropolitan factors are associated with poverty suburbanization? Poverty suburbanization growth rates and temporal changes in metropolitan level factors for 2000 and 2008 are highlighted. Change regression results reveal important macro level and within suburb effects illuminating recent changes in the spatial distribution of the poor. Positive changes in housing affordability appear to open up access to suburban neighborhoods, while metropolitan job decentralization and residential segregation have countervailing effects on the suburbanization of the poor. Findings from this paper suggest that it is appropriate to place the suburbanization of poverty in the contemporary period within an urban political economy framework of urban growth and change.
\end{abstract}

\section{Keywords}

affordable housing; job sprawl; residential segregation; suburban poor

\section{Issue}

This article is part of the special issue "Housing and Space: Toward Socio-Spatial Inclusion", edited by Dr. Dallas Rogers (University of Western Sydney, Australia), Dr. Rae Dufty-Jones (University of Western Sydney, Australia) and Dr. Wendy Steele (RMIT University, Australia).

(C) 2015 by the author; licensee Cogitatio (Lisbon, Portugal). This article is licensed under a Creative Commons Attribution 4.0 International License (CC BY).

\section{Introduction}

The changing spatial distribution of the poor in U.S. metropolitan areas is of particular concern as the suburbs now accommodate the greatest share of the poor. The share of poor in suburbs is growing at an accelerated rate, yet it is not all together clear why the spatial distribution of the poor is shifting. Suburban poverty trends suggest that there have been important changes, including a portion of the poor have likely moved outside of cities, suburban residents may be poorer because of "Great Recession" related income losses or perhaps some affluent suburban residents have relocated outside of the suburbs, among other reasons. Nevertheless, poverty once predominantly a rural phe- nomenon before the industrial revolution has shifted toward the country's largest metropolitan economic centers (Kneebone \& Berube, 2013).

Growth in suburban poverty in the contemporary period represents a departure from the historical understanding of poverty circa 1890-1970 (Macionis \& Parrillo, 2013, pp. 193-195; Mink \& O’Connor, 2004, p. 2). Immigrants and migrants alike inspired by job opportunities in U.S. cities brought on by the intensifying industrial revolution, left rural places for cities and thereafter poverty became increasingly an urban problem (Chudacoff, Smith, \& Baldwin, 2010, pp. 45-60; Jackson, 1985). Since this period, the poor have spatially spread out over the urban landscape. This includes a spreading well beyond cities and beyond older, inner- 
ring suburbs (Frey, Berube, Singer, \& Wilson, 2009). The change in the geography of poverty represents a dramatic shift in the landscape as suburbs were once places that the affluent escaped to (Hanlon, Short, \& Vicino, 2010; Wilson, 1987); currently suburbs are much more diverse, racially and economically (Howell \& Timberlake, 2014; Lee-Chuvala, 2012).

Today, a select number of suburbs grapple with what inner cities confronted about five decades earlier, serious neglect and flight of residents to newer neighborhoods beyond the urban fringe (Kneebone \& Berube, 2013, pp. 57-76; Lucy \& Phillips, 2000; Puentes \& Orfield, 2002; Puentes \& Warren, 2006). As suburban development continues to push outside of the urban fringe, employment centers have also continued to decentralize. Generally, jobs disproportionately are located in suburbs and jobs matching the skills of low wage workers in the retail and wholesale, leisure and hospitality sectors, as well as personal services sector are more often found in suburbs (Kneebone \& Berube, 2013). There is some evidence that both the spatial distribution of affordable housing and jobs are attracting a larger share of the poor to suburban destinations but the extent is unclear.

Given the acceleration and relatively new concentration of poverty in the suburbs it is important to understand the factors associated with these changes. The overarching question is what metropolitan factors are associated with how suburban the poor have become? Is there evidence that changes in affordable housing or shifts in job decentralization are salient explanations? How might structural features in metropolitan areas such as residential segregation affect the suburbanization of the poor; is it likely to slow it or accelerate growth in the share of suburban poor?

Recently, scholars have pondered questions related to the suburbanization of poverty by mainly focusing on illuminating the changing trend over the last 50 years or so. Various works have acknowledged the suburban poverty growth rate as compared to that of cities since the 1970s or 1980s (Kneebone \& Berube, 2013; Kneebone \& Garr, 2010) and others have explored the suburbanization of poor subgroups such as housing subsidized households (Covington, Freeman, \& Stoll, 2011) and poor minority groups (Howell \& Timberlake, 2014). In 1970, fewer than 24 percent of the poor were located in the suburbs of metropolitan areas; by 201055 percent of the metropolitan poor population lived in suburbs (Kneebone \& Berube, 2013, pp. 18-19). There is agreement overall that the growth in the suburban poor population began accelerating in the 1980s, reaching its height between 2000 and 2010.

The present article focuses on the spatial distribution of the poor in suburban neighborhoods of the 100 largest metropolitan areas in the nation. It is important to note that this research does not attempt to explain mobility decisions of the poor. This article extends the literature by focusing primarily on changes in the spatial distribution of the poor in suburbs. It makes the following contributions to the literature. First, current data for the most intense period of poverty suburbanization from 2000 to 2010 is analyzed with an interest in the spatial distribution of poor people across suburbs by level of income and job concentration. Prior research on the suburbanization of poverty has explored this period (Kneebone \& Garr, 2010; Covington, Freeman, \& Stoll, 2011) predominantly in a way that describes the trend but the current article uses a nuanced multivariate analysis of the largest metropolitan areas decomposing those metropolitan factors most associated with changes in the suburban poor. Second, very few multivariate examinations of suburban poverty growth have been undertaken (Howell \& Timberlake, 2014); this article offers an extension of existing multivariate analyses on the share of suburban poor. It presents estimates of the relationship between changes in the suburban poor and changes in metropolitan structural factors such as housing affordability, job decentralization, and residential segregation. In this article ideas are layout for placing recent changes in the spatial distribution of poverty in large U.S. metropolitan areas within the context of urban growth and neighborhood change.

Overall, results indicate that the growth rate of the suburban poor reveal an unprecedented opening up of suburbs to the poor. Key findings emphasize the importance of broader population changes and the heterogeneity of suburbs are crucial to understanding the suburbanization of poverty. Furthermore, changes in the spatial distribution of the poor are associated with changes in housing affordability in the suburbs. Perhaps this is related to growing rent pressures in expensive metropolitan housing markets (Bravve, Bolton, Couch, \& Crowley, 2012; Glaeser, Kolko, \& Saiz, 2001, p. 4; U.S. Census, 2003) which may be forcing lowincome households in core urban locations to seek lower rent districts in the suburbs. This has great implications, particularly for housing authorities within large metropolitan areas; housing authorities may need to reconsider how changes in the geography of poverty might prompt administrators to balance services and resources to better serve the emerging needs of suburban service areas.

Understanding factors associated with poverty suburbanization is essential for retooling suburban municipal leadership to manage important changes taking place. Generally, poor residents that have moved to the suburbs are searching for a better circumstance to make a living. Various scholars have noted that the poor and racial and ethnic minorities move to the suburbs because they desire to escape problems of the inner city, such as crime and low job access, to obtain larger and more affordable housing in the suburbs (see Pfeiffer (2012) for an extensive discussion). However, there is evidence that the spatial distribution of the 
poor in suburbs may exacerbate social and political relations within neighborhood. It is also quite possible, that future reactions from households and municipalities may lead to suburban exclusionary practices, particularly in high-amenity suburbs. Further research will be required to understand how the suburbanization of poverty may be affecting the social and political dynamics within newer suburban poor places as compared to those existing suburban poor neighborhoods.

\section{Theoretical Framework}

The primary goal of the paper is to identify factors that are associated with recent changes in the suburbanization of the poor. The main research question is what structural features in large metropolitan areas best explain changes in poverty suburbanization 2000 to 2008? The focus is on core economic, social and population characteristics of metropolitan areas. Economic characteristics and economic processes such as, housing affordability, viability of the local economy, and job decentralization are considered. Overall population changes and similarly situated poor groups are considered to discern how the spatial distribution of these groups are related to suburban poverty more generally. Residential segregation is used to highlight complicated social relationships in metropolitan areas that may be serving as push and pull forces instrumental in the suburbanization of the poor.

Ultimately, there are two primary aims of this research: 1) through an empirical analysis, illuminate major pull and push factors associated with changes in the geography of poverty and 2) place the suburbanization of poverty within a broad urban change framework. Hence, in this section, classic theories (Human Ecological Approach, Economic Theory/Rent Theory, and Political Economy) are considered as they may provide a framework for understanding the suburbanization of poverty and how it fits into a broader context of urbanization. Below each of the theories is presented along with important metropolitan factors believed to characterize the dominate relationships that are core to the theories.

It is instrumental to look at one of the most popular classical models of urban growth to classify the suburbanization of poverty. From the ecological approach, Burgess's (1925) concentric zone diagram of Chicago described the natural unfettered sifting and sorting of people and land uses across the urban landscape. Under this model, the poor spatially were generally located in close proximity to the urban core, as it was more important to be close to jobs in the inner city than to cheaper and newer housing in the commuter zone (Burgess, 1925). Post industrial revolution and for decades after, the spatial distribution of people within metropolitan areas reflected the connection that poor people had to the urban core. The fact that a dominant share of the poor now reside in the suburbs signals a departure from traditional spatial patterns. Within the context of the classic work contributed by human ecological theorists Parks and Burgess, the new trend perhaps reflects a spatial realignment of access to economic and social opportunities. Below several metropolitan level factors are considered for their influence on the spatial distribution of the poor.

\subsection{Factors Associated with Changes in the Suburban Poor}

Suburban development well outside of the urban fringe remains the dominant pattern of development within the U.S. (Glaeser \& Kahn, 2001; Bullard, Johnson, \& Torres, 2000; Jackson, 1985). On average, firm locations are affected (Kneebone, 2009) and there is mounting evidence showing that increases in job sprawl lead to job movement away from particular neighborhoods, generally away from urban neighborhoods and towards suburban neighborhoods that tend to be more racially and economically homogenous (Martin, 2001; Raphael \& Stoll, 2010). Within the contemporary context, undoubtedly, jobs continue to disproportionately locate on the suburban fringe (Glaeser, Kahn, \& Chu, 2001; Stoll, 2006). As a result, continuing job decentralization may serve as a pull factor for poor households into suburban neighborhoods.

Dynamic shifts in regional economies are important to understanding the spatial distribution of the poor. Numerous scholars acknowledge that the prosperity of the 1990s benefited poor and minority workers in ways that had not been observed during previous decades (Cherry \& Rodgers, 2000; Hines, Hoynes, \& Krueger, 2001; Holzer, Raphael \&, Stoll, 2006; Krueger \& Solow, 2001; Mishel, Bivens, Gould, \& Shierholz, 2002; Partridge \& Rickman, 2008). By 2000 unemployment rates dropped considerably for groups who had confronted persistent underemployment. During this period of economic prosperity metropolitan areas were characterized by expanded access to jobs and steep declines in concentrated poverty for blacks and Latinos alike (Jargowsky, 2003; Raphael \& Stoll, 2002).

Before the 2001 economic slowdown, economic prosperity appeared to be widespread (Freeman, 2001); by 2006 the economic climate shifted. The U.S. experienced a "Great Recession" from 2007-2012 that would cause a tremendous loss of jobs, reduce investment value, and spur the greatest foreclosure crisis since the "Great Depression" (Cochran \& Malone, 2010, pp. 331-335). The spatial distribution of foreclosures was widespread. Nearly one in ten homes with a mortgage was at risk of foreclosure during this period (Bocian, Smith, Green, \& Leonard, 2010). Both cities and suburbs were affected; however, suburban residential areas were hit extremely hard (Smetanka, 2011; McGirr, 2012). The vast majority of foreclosures were in suburban areas and suburban neighborhoods 
with higher rates of poverty were more likely to experience higher foreclosure rates (Schildt, Cytron, Kneebone, \& Reid, 2013).

Economic conditions that surfaced during the recession were likely to extend the spatial pattern of suburban poverty for several reasons. First, the economic pressures from job loss and housing foreclosure increased poverty and slowed mobility options (Schildt, Cytron, Kneebone, \& Reid, 2013). Nevertheless, perhaps it created new options for housing as a result of the unprecedented foreclosures and the rush for financial institutions to shed low value properties (Immergluck, 2012). Nationally, rental and home ownership programs such as the Neighborhood Stabilization program were designed to convert foreclosure and bank owned (REO) properties into housing that low-income buyers and renters could access (Department of Housing and Urban Development [HUD], 2014). Additionally, there is some evidence that homeowners including owners of multi-family dwellings who were experiencing the threat of foreclosure may have looked to local housing authorities to participate as a landlord in the Housing Choice Voucher (HCV formerly Section 8) program (WoTapka, 2010). Participation as a landlord in the HCV program would ensure voucher portion of the monthly rental payment. Additionally, over the period under investigation, the number of HCV recipients suburbanizing increased significantly (Covington, Freeman, \& Stoll, 2011). Hence, to the extent available, affordable housing is believed to be an essential feature in the suburbanization of poverty.

Housing and other characteristics such as: crime and transportation access, the latter two not studied explicitly here, contribute to the overall desirability of a neighborhood because of the influence it has on personal utility or quality of life (Glaeser, 2008, p. 19). According to William Alonso (1964, p. 72) "the individual will choose that point of his locus opportunities at which his utility is maximized...". Another way to think about this is that certainly people seek to connect to parcels of land that in their view allow them to reach their fullest potential. Nevertheless, the most desirable lots on average will be more expensive and hence, there are limitations to accessing land according to its cost reflective of the amenity that it represents.

Moreover, the spaces that people and firms come to occupy are a function of what they are willing to pay to obtain access to the advantages that come with the land. For example, some parcels of land improve proximity to efficient transportation routes for trade or for commuting by local residents (Giuliano, 1989, p. 145) and some parcels offer lower crime rates or pollution, thereby driving up the rent cost of the parcel (generally shown in housing price hedonic models as in Roback, 1982). This philosophical grounding is a departure from ideas that people come to occupy spaces naturally, in fact, the observed distribution of people across the ur- ban landscape is in large part due to willingness to pay (same as ability to afford) for the prime land. To further explore classic rent theory accepted wisdom within the context of the suburbanization of the poor, the spatial distribution of housing affordability and the share poor will be examined later.

In an effort to improve poor people demand for decent housing, housing options in low poverty neighborhoods were extended to the poor in the 1990s. The Department of Housing and Urban Development (HUD) as an experiment encouraged housing subsidized households to consider affordable housing options in low-poverty neighborhoods. Moving to Opportunity (MTO) demonstration project was originally authorized by Congress in 1992 and made use of rental assistance vouchers, in combination with intensive housing search and counseling services, to assist low-income families to move from some of America's most distressed urban neighborhoods (Goering et al., 1999; HUD, 2014). While many program participants moved to lowerpoverty suburban neighborhoods after counseling services, a substantial number stayed; they primarily reported strong social connections between friends and family in the central city location (Goering et al., 1999). The lack of social networks in the suburbs may push the poor away from suburban locations; however, the development of social ties overtime may increase with a growing critical mass of poor entering the suburbs. In this regard, increases in the suburbanization of Housing Choice Voucher recipients (referred to as HCVRs throughout this paper) who seem to be accompanying increases in the suburban poor more generally may indicate that suburban locations have become an important residential alternative to poor households overall (Covington, Freeman, \& Stoll, 2011).

Beyond the role of subsidized housing, the "filtering process" has been, in part, responsible for poor households entering older inner ring suburbs as higher income households moved away from housing stock that has aged in search of new higher quality housing primarily on the urban fringe (Baer \& Williamson, 1988; Lowry, 1960). Yet, gentrification and back to the city trends seem to be slightly responsible for a minority of affluent households movement away from suburbs closer to the city core, primarily within high tech corridors in the West and locations in the South and Northeast to overcome travel time constraints (Haughey, 2001; Kennedy \& Leonard, 2001; Lee \& Leigh, 2007, p. 149; Sohmer \& Lang, 2001; South \& Crowder, 1997).

The sifting and sorting of households is taking place in a housing market where affordable housing demand significantly outpaces supply (Bravve et al., 2012). The poor's access to affordable housing is significantly constrained by the limited supply. For very low-income renters, 60 adequate units are available per 100 renters (HUD, 2011, p. viii) and supply is most scarce in large metropolitan areas (Bravve et. al., 2012). The housing 
options of the poor are much more limited than those of the middle class and affluent and often their housing costs consume a majority of monthly wages.

"Units affordable for the poorest renters have lower vacancy rates than those units affordable for higher income groups because the high demand and limited supply cause greater competition for such units. Higher income renters occupy about 42 percent of the units that are affordable to extremely low-income renters, who earn less than 30 percent of Area Median Income (AMI)." (HUD, 2011, p. viii)

Given the housing shortages that the poor face, marginal shifts in housing affordability in the suburbs may attract poor households. Nevertheless, housing affordability is complicated by local policy constraints such as exclusionary zoning and other tools that may be instituted in suburban neighborhoods.

\subsection{Residential Racial Segregation}

There are several important ways that segregation may influence the rate that the poor are suburbanizing. It is essential to note that there is an important intersection between race and class present because a disproportionate number of minorities are also poor (Pattillo, 2005). Hence, I am more concerned about the association between changes in residential segregation and suburban poverty with an acknowledgement of the racial dynamic. In this case, I assert that the core connection is to deep seated structural characteristics that dominate segregated communities such as local land use policy, and real estate investment patterns.

One of the strongest most widely used local land use policies are zoning ordinances. Generally, zoning ordinances are used to control land use (Levy, 2013, p. 142). Motivated by health and safety concerns, originally zoning was critical for separating incompatible land uses and limiting the effects of externalities (Pogodzinski, 1991). Beyond the core goals, two primary forms of zoning have been used to further control land use: fiscal zoning, and exclusionary zoning. Fiscal zoning is when a jurisdiction employs zoning regulations to improve the tax base by attracting residents whose contributions to the tax base exceed their use (Pogodzinski, 1991, p. 145). Additionally, exclusionary zoning is the desire to exclude or restrict a member of some racial, ethnic, or social class from occupying a jurisdiction (Farley \& Frey, 1994; Levy, 2013, pp. 80-82). Typically, restrictions are achieved by passing ordinances that limit development in part, or in whole to single-family houses on large parcels of land (Levy, 2013, p. 80) making it very difficult for people of lesser means to live in a municipality by preventing the construction of housing that they can afford.

Some exclusionary practices have been challenged in court and precedent set by Mt. Laurel, NJ cases, for example, encourages suburban jurisdictions to eliminate exclusionary zoning ordinances and encourage the provision of affordable housing to low and moderateincome households (Levy, 2013, p. 81). Hence, while municipalities' zoning practices may have an exclusionary effect on the poor and minority households, there has been some progress to address and eliminate these practices over the last three decades that may have generated additional affordable housing options in higher income suburban neighborhoods (see the discussion in Levy, 2013, p. 82 on the abolishment of Regional Contribution Agreements in New Jersey as evidence that loopholes to circumvent jurisdiction fair share responsibilities are being given some consideration). Nevertheless, exclusionary practices exercised suggest that residential segregation in the suburbs may have a push effect on the suburbanization of the poor.

Secondly, uneven development affects us all but leaves behind the poorest members of society (Gotham, 2002). Lessons from Henri Lefebvre (1994) on the power of those that control real estate investment provide the context for this view. The French sociologist asserts that the spatial distribution of people along the urban landscape is influenced by institutions and individuals whose real estate investment decisions are determined by potential political, economic and social gain. Indeed, in the U.S. there are examples of powerful real estate actors exercising control over real estate investment. In the early 1920s the National Association of Real Estate Brokers (NAREB) promoted in a training document published in 1922 that "the purchase of property by certain racial types is very likely to diminish the value of other property" (U.S. Commission on Civil Rights, 1973, p. 3). Thereafter the national organization, the powerful governing body of realtors, NAREB, promoted a "code of ethics" that encouraged the restriction of real estate property to nonwhites as a performance of some sort of fiduciary responsibility to white residents. Nationally, for decades real estate agents and other real estate actors performed their professional tasks upholding the original code of ethics thereby deeply affecting the pattern of real estate investment in U.S. metropolitan areas (Gotham, 2000; Helper, 1969).

Later, the power of those that controlled real estate investment is observed during the period of Urban Renewal and the construction and maintenance of Public Housing (Barron \& Barron, 1965). In each case, the actual investments or lack thereof motivated by profit seeking became the deciding factor in the stability, decline or revival of neighborhoods. Except in cases where local interest organized against such uneven development as did Jane Jacobs when she helped to organize New York City residents against Urban Renewal (Jacobs, 1961). It appears that real estate investments push the growth of a city and perhaps even of a met- 
ropolitan region in particular ways. Among other factors, residential segregation may play an important role in the growth rate of suburban poverty, potentially spurring movement toward suburbs or constraining access for certain groups.

Along with other important metropolitan features, residential segregation has dynamically shifted in the recent period. The 2000 segregation levels mark the lowest levels recorded since 1920. According to Glaeser and Vigdor (2001, pp. 13-14) 43 metropolitan areas witnessed a decline in segregation greater than 10 percent. Despite, persistently high rates of residential segregation between White and African Americans, overall it declined by 5.5 percent from 1990 to 2000 (Glaeser \& Vigdor, 2001, p. 1). These shifts may be reflective of changes in the social and political dynamics present within metropolitan areas. For example, shrinking residential segregation trends may be related to the adoption of more inclusive zoning policies by the municipality. Suburban communities committed to incorporating a more diverse set of housing options affordable to low and moderate-income households likely shift the geography of poverty. In the following section, the data and methods for analyzing the relationship between recent increases in the suburban poor and metropolitan factors such as residential segregation are presented.

\section{Data and Methods}

Several data sources are required to address the overarching research question: what metropolitan factors are associated with the suburbanization of the poor? First, data for the population characteristics used to develop suburban poverty rates, the description of suburbs by income and fair market rate housing came from the 2000 U.S. Decennial Census and the 5-year, 2005-2009, American Community Survey (ACS). The ACS is the former decennial census "long form". The ACS long form is conducted annually utilizing smaller samples than the decennial census. Five-year estimates are used since multiple years worth of summary data are more reliable than the single year summary files. These data were originally organized by tract for the largest 100 MSAs and later average values for each MSA were computed. Data from 2000 and 2008 were ultimately merged by MSA using the statistical software system STATA. Following is a brief discussion about how suburbs were defined.

The suburbs are defined using U.S. Census Bureau definitions, and census tracts are identified as cities or suburbs based on the location of their centroid; those census tracts that cross city or suburban boundaries are allocated to either area based on whether their centroid falls in either location. Metropolitan statistical area (MSA) definitions are consistent with the U.S. Office of Management and Budget definitions in 2008. Primary cities are defined according to the methods outlined in several Brookings publications (e.g., Berube \& Kneebone (2006)), and include those that appear first in the official MSA name, as well as any other city in the MSA title that has a population of at least 100,000 .

The alternative method is to assign census tracts to cities or suburbs based on their population distributions at the block level. In this way, an allocation factor is generated using this method that estimates whether the population density is greater in the city or suburban portion of the census tract, and is assigned as such. This approach was not employed because the population density of HCV recipients could not be determined since the lowest geographic level of information provided on residence is at the census tract level.

Second, data from HUD's Picture of Subsidized Housing 2000 and 2008 are used to generate a comparison group of Housing Choice Voucher Recipients (HCVRs). This data set describes the characteristics of HUD assisted housing including the type of program, and population characteristics of the assisted households at the census tract level. As such, the Picture of Subsidized Housing allows us to identify the geographic location of HCV recipients as well as key demographics such as their race/ethnicity.

Third, the suburbs are characterized by their variation in job accessibility. Data for employment counts are from the U.S. Department of Commerce's ZIP Code Level Business Patterns data, which of course is only available at the ZIP code level. These data provide information on the number of firms in a zip codes as well as data on their employment size, sales figures, as well as other establishment economic and characteristic data. Job accessibility is the ratio of people (ages 21 to 64) to total jobs in zip codes in 2000 and 2008 for the largest 100 metro areas in the sample. To generate equivalent geographic comparison with the HCV recipients' data, census tracts were converted to zip codes using a centroid based allocation method, similar to that described above.

\subsection{Dependent Variables}

The dependent variable is the difference in the share poor in suburbs 2000 and 2008. This variable is computed by generating the share of the poor that reside in suburban tracts for the 100 largest MSAs in the nation. Two cross-sections are obtained and the average share poor in suburbs is tallied for each MSA, 2000 and 2008. For the second set of dependent variables metropolitan area suburban tracts are organized into income treciles (low, medium and high) and mean poverty percents for each group are generated by MSA. Similar to above, suburban poverty growth rates were generated for low-income, middle-income and high-income suburbs for 2000 and 2008 cross-sections. The descriptive results presented below indicate that suburban poverty has increased over 2000 to 2008; nevertheless, these re- 
sults do not consider the various factors that are associated with suburban poverty growth. Table 1 displays all the dependent variables used in the study. The multivariate analysis takes into consideration various metropolitan characteristics also specified in Table 1.

A key concern in analyzing data at the submetropolitan level is how to define these areas, especially those within the suburbs. For instance, some use a county based definition, in which "first" suburbs are defined as central counties (excluding the central cities in those counties) and any county adjacent to the central city. But such a definition is problematic, in that adjacent counties (e.g., Montgomery County, MD, which is adjacent to Washington, DC) can often have quite heterogeneous populations. They can also have quite high average incomes. On the other hand, defining submetropolitan areas on the basis of municipalities is also problematic, as municipalities can vary enormously in size and jurisdiction. In this paper, this issue is avoided by using aggregate census tract data, which are small enough to capture the enormous heterogeneity across areas.

\subsection{Independent Variables}

To begin to understand the features within metropoli- tan areas that are associated to the suburbanization of poverty a number of comparisons are made. The suburbanization of the total population, HCVRs and affordable housing units are highlighted in the paper. The suburbanization of the total population is computed nearly identical to the share poor measure, the main difference is that the focus is on the total population. The average rate is generated by computing the share for each suburban track comprising MSAs.

HCVRs are an important subset of the poor. It is expected that the poor receiving housing subsidies should provide an excellent comparison for what one would expect to observe for the overall poor. In fact, the characteristics of HCVRs suggest that they are a more disadvantaged group than the poor generally. Suburbanization of Housing Choice Voucher recipients was measured using data from HUD's Picture of Subsidized Housing. As such, the Picture of Subsidized Housing allows us to identify the geographic location of HCV recipients as well as other key demographics. The data were extracted for the years 2000 and 2008.The paper includes comparisons of the suburbanization rates of the poor overall to HCV recipients and affordable housing over the same period.

Table 1. Description of dependent and independent variables (weighted).

\begin{tabular}{|c|c|c|c|c|c|c|}
\hline Dependent Variables Description & $\begin{array}{l}2000 \\
\text { Mean }\end{array}$ & $\begin{array}{l}2008 \\
\text { Mean }\end{array}$ & $\begin{array}{l}\text { 2000-2008 } \\
\text { Mean }\end{array}$ & Min. & Max. & $\begin{array}{l}\text { Std. } \\
\text { Deviation }\end{array}$ \\
\hline $\begin{array}{l}\mathbf{\Delta 0 0 - 0 8} \text { MSA Poverty Suburbanization rate: } \\
\text { average share of poor enumerated by } \\
\text { suburban tracts, difference } 2008-2000\end{array}$ & 0.503 & 0.536 & 0.033 & -0.042 & 0.139 & 0.024 \\
\hline $\begin{array}{l}\Delta \text { Low-Income Suburbs Share Poor } \mathbf{0 0 - 0 8} \\
\text { MSA average share of poor enumerated for } \\
\text { low-income suburban tracts, difference } \\
2008-2000\end{array}$ & 0.392 & 0.397 & -0.006 & -0.260 & 0.090 & 0.051 \\
\hline $\begin{array}{l}\Delta \text { Moderate-Income Suburbs Share Poor 00- } \\
08\end{array}$ & & & & & & \\
\hline $\begin{array}{l}\text { MSA average share of poor enumerated for } \\
\text { moderate-Income suburban tracts, difference } \\
2008-2000\end{array}$ & 0.387 & 0.368 & -0.018 & -0.170 & 0.120 & 0.037 \\
\hline $\begin{array}{l}\mathbf{\Delta H i g h - I n c o m e ~ S u b u r b s} \text { Share Poor } \mathbf{0 0 - 0 8} \\
\text { MSA average share of poor enumerated for } \\
\text { high-Income suburban tracts, difference } \\
2008-2000 \\
\text { Independent Variable Descriptive Statistics }\end{array}$ & 0.215 & 0.240 & 0.026 & -0.044 & 0.195 & 0.038 \\
\hline Independent Variables Description & $\begin{array}{l}2000 \\
\text { Mean }\end{array}$ & $\begin{array}{l}2008 \\
\text { Mean }\end{array}$ & $\begin{array}{l}\text { 2000-2008 } \\
\text { Mean }\end{array}$ & Min. & Max. & $\begin{array}{l}\text { Std. } \\
\text { Deviation }\end{array}$ \\
\hline$\Delta$ Suburban Growth Rate $08-00$ & 0.676 & 0.691 & 0.015 & -0.021 & 0.084 & 0.018 \\
\hline$\triangle$ Suburban HCVR Growth Rate 08-00 & 0.473 & 0.494 & 0.021 & -0.160 & 0.193 & 0.059 \\
\hline$\Delta$ Suburbanization of $50 \%$ FMR Units $08-00$ & 0.443 & 0.472 & 0.028 & -0.074 & 0.216 & 0.037 \\
\hline$\Delta$ Suburbanization of FMR Units $08-00$ & 0.504 & 0.529 & 0.025 & -0.026 & 0.156 & 0.025 \\
\hline$\Delta$ Percent College Educated $2508-00$ & 27.1 & 29.9 & 2.83 & -0.030 & 4.60 & 0.941 \\
\hline $\begin{array}{l}\Delta \text { Ratio of NHW male } 16-64 \text { employed to } \\
\text { persons } 08-00\end{array}$ & 0.813 & 0.771 & -0.042 & -0.230 & 0.010 & 0.023 \\
\hline $\begin{array}{l}\Delta \text { Black-White Segregation (Dissimilarity } \\
\text { Index) } 08-00\end{array}$ & 0.632 & 0.622 & -0.008 & -0.150 & 0.330 & 0.051 \\
\hline$\Delta$ Job Sprawl 10 miles $08-00$ & 0.435 & 0.415 & -0.021 & -0.210 & 0.060 & 0.028 \\
\hline$\Delta$ Percent Foreign Born Hispanic 08-00 & 34.8 & 38.9 & 4.1127 & -4.58 & 16.16 & 3.65631 \\
\hline
\end{tabular}


The suburbanization of rental units renting 50 percent below Fair Market Rate (FMR) levels is compared to the poor suburbanizing. This was done by identifying the number of rental units reported in the 2000 Census and 2005-2009 American Community survey that fell at and below the FMRs reported by HUD for those years for each respective metropolitan area. Whereas the comparisons with suburbanization of HCVRs will elucidate the extent to which poorer households in general are locating in the suburbs regardless of the affordability levels, the comparison with units 50 percent below metropolitan specific FMRs will give us a sense of the availability of affordable housing options in suburbs. While FMR units are defined as reasonably priced housing it is still very difficult for poor households unsubsidized to secure affordably priced housing. Take for example the Los Angeles-Long Beach metropolitan area, the FMR for a 2 bedroom unit is $\$ 1,421.00$ (HUD, 2013). For the average poor household making about $\$ 19,000.00$, the poverty threshold for the typical sized family of 4, two adults and two children would pay over 50 percent of their monthly income on housing expenses. The 50 percent FMR measure is an affordable housing measure necessary to more precisely capture housing affordable for households in poverty.

Suburban areas are characterized by income level and by job accessibility. First, median household income data for 2008 from the 2005-09 ACS and for 2000 from Census $\mathbf{2 0 0 0}$ for each census tract for all metro areas in the study are obtained. Household income treciles (33rd, 66th percentiles) are calculated for each metro area for both years. Next, high-income census tracts are defined as those that fall between the 66th and 100th percentile in the median income distribution of the metro area, moderate-income between the 33rd and 66th percentile in the distribution and low-income as below the 33rd percentile in the distribution. Given this, highincome suburban areas are defined as those with suburban census tract median income levels that fall above the 66th percentile of metro area, and this is continued for each trecile which generates three suburban income groups (low, moderate and high).

Second, suburban areas are characterized by their variation in job accessibility using the same method, except zip code level sub-geography units are used. Employment counts from the U.S. Department of Commerce's ZIP Code Level Business Patterns data provide the main jobs data, which of course is only available at the ZIP code level. These data provide information on the number of firms in a zip codes as well as data on their employment size, sales figures, as well as other establishment economic and characteristic data. Job accessibility is defined as the ratio of people (ages 21 to 64) to total jobs in zip codes in 2000 and 2008 for the largest 100 metro areas in our sample. Utilizing the income and job accessibility suburban tract distinctions, low-income to high-income subur- banization of poverty rates are generated as were low job to high job accessible suburbanization of poverty rates. These variables measure the extent to which the poor have come to occupy prime suburbs, those suburbs that seem to offer increased access to economic and social opportunities (i.e. jobs, good schools, low crime rates, etc.).

Additional variables of concern are residential segregation, job sprawl and economic robustness measured by white male worker employment. The strength of the labor market can be measured by the extent to which white men find gainful employment. This can also be viewed as a measure that more directly describes the robustness of a job market because white men arguably experience fewer constraints, such as discrimination, in finding work (Cherry \& Rodgers, 2000).

The primary measure of residential segregation is computed using the index of dissimilarity; this is also the most commonly used measure of segregation, but not the only one in the segregation literature. Others include the isolation, exposure and entropy indexes, for example, and these measure different aspects of the scope or kind of segregation. These alternative measures of segregation are well noted in the literature and their differences and consequences have been examined elsewhere as alternative measures of segregation (Massey \& Denton, 1993). Alternative measures of segregation were explored, however, the dissimilarity index provided the most stable measures as identified during analysis and thus their results are not reported.

The data used to measure the index of dissimilarity comes from the 2000 U.S. Census and the 2005-2009 ACS. The dissimilarity score between blacks and whites is given by:

$$
D=\frac{1}{2} \sum_{i}\left|\frac{\text { Black }_{i}}{\text { Black }}-\frac{\text { White }_{i}}{\text { White }}\right| .
$$

where Blacki is the black population residing tract $i$ (where $\mathrm{i}=(1, \ldots, n)$ and indexes the tracts in a given metropolitan area), Whitei is the white population residing in tract $i$, Black is the total black population in the metropolitan area, and White is the total number of whites in the metropolitan area. The dissimilarity index ranges between 0 (perfect integration) and 1 (perfect segregation). Indexes of dissimilarity are calculated for white-black pairings for 2000 and 2008. There are a number of potential problems with the use of the dissimilarity index to measure residential segregation. First, although it measures evenness of population distribution, it may not actually measure the physical distance between average members of two racial groups. The index measures the imbalance across geographic sub-units of the metropolitan area (for example, tracts) between members of the population. To take an extreme example, suppose that all black residents resid- 
ed in one tract of a city while white residents were located in a different tract. Whether these tracts are one mile apart from one another or 20 miles apart will not influence the dissimilarity measure. In both instances, the dissimilarity index will be equal to 1 . Nonetheless, as a summary measure, the dissimilarity measure does allow uniform comparisons across geographic areas.

Despite these concerns, there are a number of strengths of the dissimilarity index. It allows for residential segregation to be measured in a uniform way across metropolitan areas. The dissimilarity measure is calculated in the exact way across metropolitan areas using the same data sources and thus allow for direct metropolitan area comparisons.

Further, the actual numerical value of the dissimilarity index has a convenient interpretation. Specifically, the index can be interpreted as the percent of either of the two racial groups that would have to relocate to different areas to completely eliminate any geographic imbalance. For example, as Table 1 indicates, the 2000 index value describing the imbalance between the residential distribution of blacks and whites is 0.559 (or 55.9 when multiplied by 100 ) on average for all metropolitan areas in the study.

Job sprawl is measured by observing the percent of jobs 10 miles outside of the CBD. Three mile and five mile radius measures outside of the CBD were also considered. This variable is an improvement over jobs per capita because it captures relative job decentralization. Analysis on how job movement away from the core of the central business district influences the suburbanization of poverty may provide additional information about how relative geographical changes in labor demand may be affecting the location decisions of the poor. It is expected that as jobs decentralize it may serve as a pull factor for the poor to relocate outside of the central city and towards the urban fringe. The job sprawl data are drawn from the 1999 U.S. Department of Commerce's ZIP Code Business Patterns files, and have been used elsewhere (Glaeser \& Kahn, 2001; Stoll, 2006). Job sprawl is defined as the proportion of metropolitan jobs located outside of a 10 mile radius of the metropolitan area's Central Business District (CBD), and it has a straightforward interpretation: higher percentages of a metropolitan area's employment located outside the 10 mile ring around the CBD implies higher sprawl.

A set of demographic variables are included in the analysis. Percent in college, percent foreign born Hispanics are included as controls in the analysis. Descriptions of the measures are presented in Table 1. The following section describes the empirical results.

\section{Results}

\subsection{Descriptive}

For the analysis suburban poor growth rates and tem- poral changes in metropolitan level factors for 2000 and 2008 are highlighted. Overall, the suburbanization rate of the overall population in 2008 was 0.691 and the poor suburbanization rate was 0.536 (refer to Table 1). Fair market rate housing and Housing Choice Voucher recipients (HCVRs) overall are suburbanizing at a lower rate than the poor overall at 0.529 and 0.494 respectively. Relatively reasonably priced housing seems to be suburbanizing at a rate slightly lower than the poor overall (3.3 percent). Affordable housing, that which is 50 percent of FMR suburbanized 2.8 percent versus 2.5 percent for FMR housing over the period. Moreover, other poor groups such as HCVRs are suburbanizing at a slower rate; the HCVR share in suburbs grew 2.1 percentage points. These changes over the decade outpaced the suburbanization of the overall population at 1.5 percentage points.

\subsection{Poverty Suburbanization and Suburb Type}

This section explores the types of suburbs that the poor reside in. The spatial distribution of the poor is compared to that of the overall population, other poor groups and affordable housing. This examination is important because recent research has demonstrated that suburban areas differ widely in their socioeconomic characteristics and in the types of opportunities they offer, with lower income suburbs demonstrating slower employment growth (and faster population growth) over the recent decade that is likely to negatively influence employment opportunity and economic mobility prospects more generally. Today, the quality of the suburbs varies tremendously (Kneebone \& Berube, 2013; Mikelbank, 2004; Lee-Chuvala, 2012) potentially causing a wide distribution in the desirability of suburban neighborhoods. Therefore, an important question is which type of suburbs are the poor disproportionately located? And does the growth rate seem to be associated with suburban characteristics such as: affordable housing and jobs?

Figure 1 documents the distribution of the poor (and the comparison groups) across suburbs in 2008. The data show that despite the increase of the poor locating to high-income suburban areas over the 2000 to 2008 period (see Figure 2), that by 2008 a plurality of the poor (40 percent) still lived in low-income suburbs. Moreover, in relation to the comparison groups, $\mathrm{HCV}$ recipients (48 percent) are most disproportionately located in low-income suburbs. A higher share of poor people live in low-income suburbs for a variety of reasons, some obvious and others not so obvious. First, reports from evaluations of the MTO program documented respondent statements explaining that program participants even after receiving counseling about suburban neighborhood opportunities, did not choose to relocate because they did not want to move away from friends and family, and other social networks (Goering 
et. al., 1999). Additional justifications for staying are associated with asymmetrical information (lack of information about options), fear of discrimination, and lack of transportation (reliable car and difficulty accessing public transportation) (de Souza Briggs, 1998).

Affordable housing options are expected to be important to the mobility of the poor. Fair market rate housing is defined as reasonably priced housing and $50 \%$ fair market rent is on average $50 \%$ below the area median (in this paper $50 \%$ FMR is referred to as affordable housing). The dominant share of affordable housing is located in low-income suburbs (47 percent). On average, about 17 percent of affordable housing exists in high-income suburbs. Generally, during the period 2000-2008 the only aggregate growth in housing affordability is observed in high-income suburbs in the largest $\mathbf{1 0 0}$ metropolitan areas in the U.S. (see Figure 2). Perhaps persistent difficult housing affordability conditions in high-income areas render these suburbs prime areas for marginal increases in housing affordability since low and moderate-income suburbs have the greatest share of affordable housing. Moreover, recently more affordable housing is being built with seniors in mind. Federal programs such as the Low Income Housing Tax Credit (LIHTC) program funds may be instrumental in marginal increases in average housing affordability in high-income suburbs.

Figure 2 shows the change in the distribution of the poor (and the comparison groups) across desirable features of suburban neighborhoods over the 2000 to 2008 period. Attention is focused on high-income sub- urbs and note that the poor population made gains over this period in locating to high-income suburbs, the pace of that change was more accelerated than the other comparison groups. For example, the growth in affordable housing was most pronounced in highincome suburbs; likely a precursor for the accelerated movement of the poor to high-income suburbs. A comparison poor group, HCVRs living in high-income suburbs, increased by 2.1 percentage points over the period while, the largest declines for HCVRs were in low-income suburbs. The temporal changes in the share of poor by the income of the suburbs 2000 to 2008 indicate that most of the growth in suburban poverty occurred in high-income suburbs and also in high job accessibility suburbs.

Figure 2 also shows average differences in the share of poor by the job accessibility of the suburbs. Job access is desirable. By 200828.5 percent of the poor reside in high job access suburbs and their growth rate (2.7) is slightly beyond that of the total population growth rate (2.1). HCVRs, arguably more at risk than the poor generally (Schwartz, 2013) have a slightly accelerated growth rate. On average, there is a 2.8 percent growth rate in HCVRs in high job accessible suburbs. Despite growth in suburban poverty in highincome suburbs, generally speaking, the dominant share of the poor reside in medium and low job access suburbs (see Figure 1). There was a surprising 4.5 percentage point growth in affordable housing in high job accessible suburbs. Nevertheless, the lions-share of affordable housing is in low job accessible suburbs (40.9 percent).

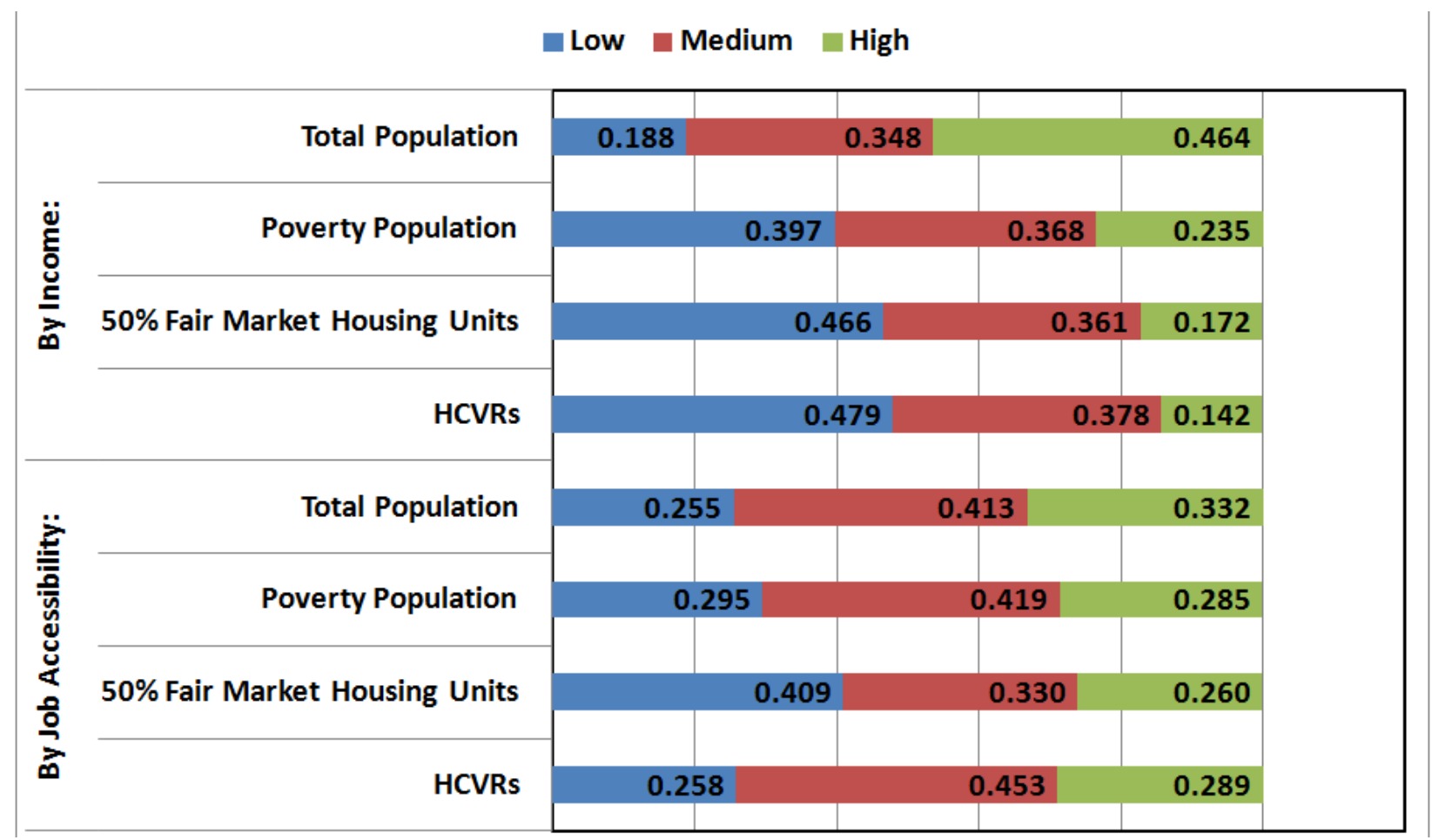

Figure 1. Distribution of total population, poor, HCVRs and FMR by select suburban characteristics, 2008. Source: author's analysis of HUD data, Census 2000 and ACS five-year estimates 2005-2009, an early version of the figure is presented in Covington, Freeman and Stoll (2011). 


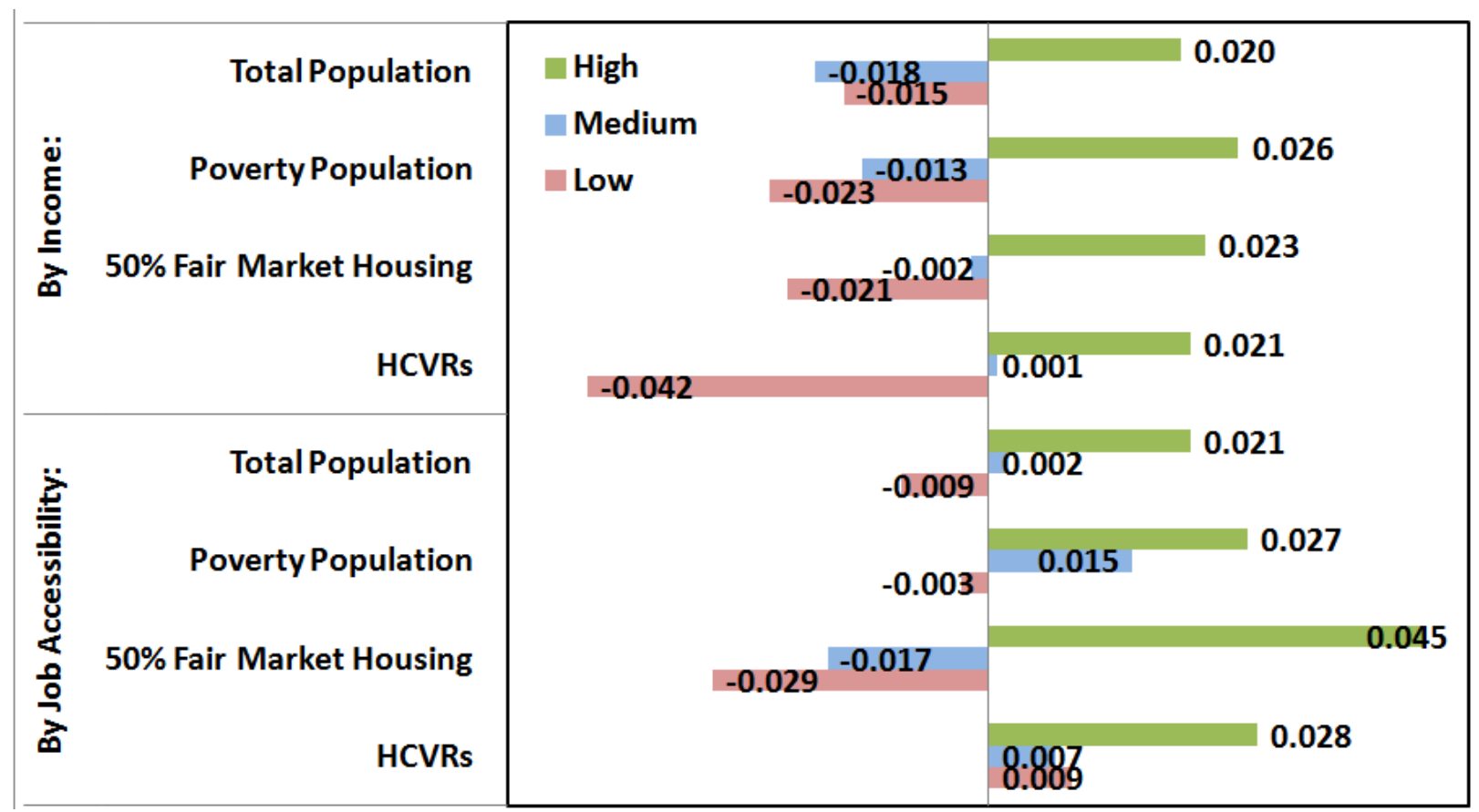

Figure 2. Change in distribution of population, poor, FMR Units and HCVRs by select suburban characteristics, 2000-2008. Source: author's analysis of HUD data, Census 2000 and ACS five-year estimates 2005-2009, an early version of the figure is presented in Covington, Freeman and Stoll (2011).

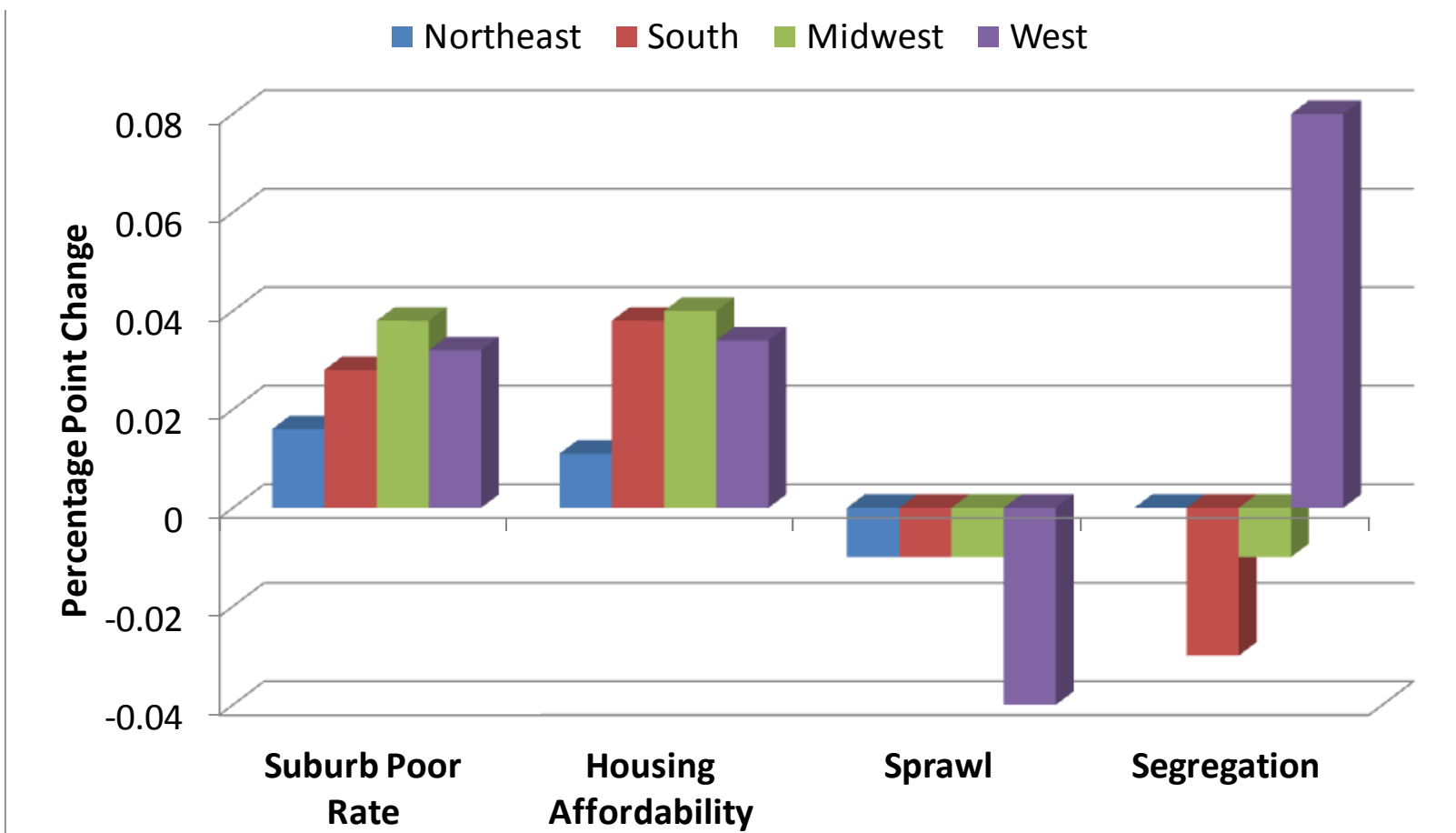

Figure 3. Regional differences in the change of key metropolitan features, 2000 to 2008 . Source: author's analysis of HUD data, Census 2000 and ACS five-year estimates 2005-2009.

Further descriptive analysis show some regional differences in key variables examined in this paper. Figure 3 shows, on average, suburban share poor and housing affordability is increasing across all regions nevertheless, the northeast regions seems to be increasing at a slower pace than the other three regions. On average, job sprawl measured at the 10 mile radius has declined for all regions and most dramatically for metropolitan areas in the West. Larger differences are observed for residential segregation. Figure 3 shows that residential segregation has declined over the decade for metropolitan areas in the South and Midwest. Larger increases in segregation have occurred in the West while, segregation in the Northeast on average stayed steady and did not show much change.

The differences in the share of the suburban poor 
by type of suburb and region provide a glimpse of the factors important to the suburbanization of poverty. Nevertheless, the bivariate relationships highlighted here provide a limited view of what factors are actually associated with the growth in the suburban poor. In the next section results are presented for 1st difference regressions for suburban poor share 2000-2008.

\subsection{Multivariate Analysis}

Table 2 introduces a series of base multivariate change regression models important for establishing the general macro factors associated with the growth of the suburban share poor across metropolitan areas. Model 1 is the base model and Model 2 applies demographic controls. The demographic variables include \% college educated used to account for relative high education of the population, \% employment white males is used to account for the average robustness of the job market, and \% foreign born Hispanics as one of the largest groups of immigrants in the U.S. is used to account for average changes in percent of immigrant residents within recent years. The dependent variable is the change (between 2000 and 2008) in the rate of suburban poor. Both unweighted and weighted beta coefficients are presented. Weighted results are discussed.

Model 1 shows a generally strong and stable association (0.432) between growth in share of suburban population and growth in the share of suburban poor. It is not surprising that these data suggest that the growth in suburban share poor is associated more generally with growth in the share of suburban population. These findings support dominant trends of population movement towards suburbs. The decentralization of the human population in the U.S. is a prominent feature of U.S. metropolitan areas (Lopez \& Hynes, 2003; Heinlich \& Anderson, 2001; Frey \& Geverdt, 1998; Palen, 1995) and historically, as more affluent residence locate in the suburbs, jobs and poorer residents followed (Martin, 2001). Lessons from the place stratification model may be applicable here; the model anticipates that the rate of poor suburban settlement will lag the suburbanization of more affluent residents.
Overall, the relationships viewed in base Model 1 hold after controls are included in Model 2.

How important are changes in affordable housing to changes in suburban share poor? On average, increases in the suburban share of affordable housing is associated with a 0.228 increase in the share of suburban poor as indicated by Model 2. It appears that there is a consistent positive relationship between affordable housing and the suburban poor growth rate. Approximately one unit increase in affordable housing in suburbs on average over the study period was associated with a 0.2 percentage point increase in the poor suburban share. These results provide evidence that growth in housing affordability is very important to recent changes in the spatial distribution of the poor. It appears that affordable housing changes across suburbs are associated with a change in suburban share poor. This result will be explored more deeply within suburbs according to income in later sections.

\subsubsection{Macro between Suburban Metropolitan Results}

How do changes in macro level metropolitan structural features such as job sprawl (also referred to as job decentralization) and residential segregation influence the growth rate of the suburban poor? Table 3 introduces two models that help to address this question. First, as a macro metropolitan pull factor, positive changes in affordable housing are much more important than job decentralization. The decentralization of jobs ten miles outside of prominent CBDs across the metropolitan area do not appear to be significantly associated with growth in the share of suburban poor. Although 41.5 percent of jobs are 10 miles outside of the CBD on average in the largest MSAs in the nation, the growth rate declined 2 percentage points between 2000 and 2008 (see Table 1). It is quite possible that the change in job sprawl does not fluctuate enough between decades to capture a magnitude of change large enough to influence the share of poor in suburbs. In the future perhaps a twenty year period of job sprawl change would make a difference in the measurement and in the analysis.

Table 2. 1st difference multivariate regression of suburban share poor $2000-2008(N=100)$.

\begin{tabular}{|c|c|c|c|c|}
\hline & Model 1 & & Model 2 & \\
\hline & $B$ & Weighted & $B$ & Weighted \\
\hline \multirow[t]{2}{*}{ Intercept } & $0.009 * *$ & $0.022^{* * *}$ & 0.002 & 0.018 \\
\hline & $(0.004)$ & $(0.003)$ & $(0.012)$ & $(0.013)$ \\
\hline \multirow{2}{*}{$\Delta$ Suburban Rate Total Pop } & $0.527^{* * *}$ & $0.432 * * *$ & $0.541 * * *$ & $0.499 * * *$ \\
\hline & $(0.130)$ & $(0.128)$ & $(0.136)$ & $(0.151)$ \\
\hline \multirow[t]{2}{*}{$\Delta$ Suburban Rate HCVRs } & $0.101 * * *$ & 0.004 & $0.083^{* *}$ & -0.002 \\
\hline & $(0.037)$ & $(0.039)$ & $(0.040)$ & $(0.040)$ \\
\hline \multirow[t]{2}{*}{$\Delta$ Suburban Rate $50 \%$ FMR } & $0.207 * * *$ & $0.204 * * *$ & $0.216 * * *$ & $0.228 * * *$ \\
\hline & $(0.059)$ & $(0.063)$ & $(0.063)$ & $(0.065)$ \\
\hline Demographic Variables & - & - & $x$ & $x$ \\
\hline ADJ $R^{2}$ & 0.307 & 0.196 & 0.290 & 0.196 \\
\hline
\end{tabular}

Note: ${ }^{*} p<0.10, * * p<0.05, * * * p<0.01$ 
On the other hand, residential segregation across metropolitan areas serves as a push factor for the suburbanization of the poor. As suspected, pervasive residential segregation across U.S. metropolitan areas is associated with slowing the growth rate of the suburban poor. Although residential segregation between black and white residents is still relatively high the trend is downward. In 2008 average black-white segregation was 62 percent and it decreased 0.88 percentage points over the period. The segregation change regression coefficients in Table 3 indicate that on average segregation is associated with a 0.135 unit deceleration of the suburban poor rate. Hence, to the extent that residential segregation exists within metropolitan areas, the political and social dynamics that bring about segregation patterns also limit the poor's access to suburban neighborhoods. Later, I will explore if the results vary by the heterogeneity of the suburb. That is, does segregation have the same effect on all suburban neighborhoods within metropolitan area? Results of more extensive analyses of affordable housing, job decentralization and residential segregation effects are presented below.

\subsubsection{Within Suburban Metropolitan Results}

Descriptive statistic results from above suggest that the stratification of the suburbs may be important to differences in the spatial distribution of the suburban poor. The differences in suburban population by type of suburb presented in Figure 1 suggested that there are differences by suburb large enough to influence the slope of the relationship between the dependent and series of explanatory variables. In this section, an analysis of changes in suburban poor share by the income heterogeneity of the suburb will further describe how important factors within suburb are associated with changes in the suburban poor share. Ultimately, a comparison of results will indicate whether there are important differences by quality of the suburb such as socio economic status (income) and whether macro level results hold.

Table 4 displays first difference regression models for suburbs disaggregated by the income of the suburb. Recall that income group was designated by trecile distribution of average income for suburban tracts within each MSA. Each model represents an analysis for one of three types of suburbs, low-income, moderateincome and high-income suburbs. Therefore, the LowIncome Model displayed in Table 4 are the results of an analysis of the change in the share of poor in lowincome suburbs and the independent variables represent values for low-income suburbs except for job sprawl and residential segregation, generally the computation for these variables requires an enumeration up to a unit larger than a tract (computed at the MSA unit for this paper). In this case, I am interested in whether changes in metropolitan structural features such as job sprawl and residential segregation influence changes in the distribution of the suburban share poor in low-income suburbs, differently than moderate-income and high-income suburbs.

Table 4 shows some important differences within suburb. First, I will focus on the HCVR result. Unlike the macro models in Table 2 and Table 3, the weighted results of HCVRs reveal a positive significant relationship across each suburb income group. Generally, changes in the rate of HCVRs in low, moderate and high-income suburbs have a corresponding positive association to changes in the suburban poor share, $0.105,0.154$ and 0.083 respectively. The heterogeneity of suburb seems to matter for the association of HCVR and suburban poor share. It may matter because there are very pronounced differences in HCVRs absorption into suburban neighborhood primarily because of selection. To start, generally HCVRs are even more disadvantaged than the poor and only about 14.2 percent reside in high-income suburbs of which a disproportionate share are white HCVRs (Covington, Freeman, \& Stoll, 2011). These differences seem to signal qualitative differences in the HCVR population and the places they reside. On average, the significant positive results reveal that suburban changes in HCVRs move with suburban changes in the poor share, potentially supporting the idea that other poor groups perhaps through available networks to information about housing and other opportunities likely attract other poor residents (Goering, et. al., 1999).

Within suburb effects displayed in Table 4 show that the heterogeneity of the suburb is a necessary distinction when observing the association between changes in affordable housing and changes in the poor share. The Moderate-Income Model reveals the only significant positive relationship among the suburb groups. There is an associated 0.215 change in the share poor in moderate-income suburbs with an accompanied one unit change in affordable housing in moderateincome suburbs. Why only moderate-income suburbs? As shown in Figure 1, approximately 36 percent of affordable housing is located in middle-income suburbs and this share is steady over the decade while lowincome suburbs have experienced the largest declines over the period. Housing affordability at least over this period seem to be more steady and perhaps various efforts to extend affordable housing in these neighborhoods such as mixed-income and transit oriented development that utilize programs such as the Low Income Housing Tax Credit (LIHTC) and efforts focused on affordable senior housing may contribute substantially to the dynamic. Also, middle-income neighborhoods may be experiencing an introduction of housing filtering as these neighborhoods are aging as well. 
Table 3. 1st difference multivariate regression of suburban share poor, $2000-2008(\mathrm{~N}=100)$.

\begin{tabular}{|c|c|c|c|c|}
\hline & Job Decentralization & & Residentic & \\
\hline & $B$ & Weighted & $B$ & Weighted \\
\hline \multirow[t]{2}{*}{ Intercept } & 0.004 & $0.023^{*}$ & 0.004 & 0.019 \\
\hline & $(0.013)$ & $(0.014)$ & $(0.012)$ & $(0.014)$ \\
\hline \multirow[t]{2}{*}{$\Delta$ Suburban Rate Total Pop } & $0.528 * * *$ & $0.492^{* * *}$ & $0.559 * * *$ & $0.524 * * *$ \\
\hline & $(0.138)$ & $(0.153)$ & $(0.135)$ & $(0.149)$ \\
\hline \multirow[t]{2}{*}{$\Delta$ Suburban Rate HCVRs } & $0.092 * *$ & 0.001 & $0.083^{* *}$ & 0.005 \\
\hline & $(0.041)$ & $(0.041)$ & $(0.041)$ & $(0.040)$ \\
\hline \multirow[t]{2}{*}{$\Delta$ Suburban Rate $50 \%$ FMR } & $0.233 * * *$ & $0.230 * * *$ & $0.229 * * *$ & $0.220 * * *$ \\
\hline & $(.065)$ & $(0.067)$ & $(0.064)$ & $(0.065)$ \\
\hline \multirow[t]{2}{*}{$\Delta$ Job Sprawl 10} & 0.017 & 0.087 & 0.016 & 0.087 \\
\hline & $(0.079)$ & $(0.087)$ & $(0.078)$ & $(0.085)$ \\
\hline \multirow[t]{2}{*}{$\Delta$ Black-White Segregation } & & & $-0.095^{* *}$ & $-0.135 * *$ \\
\hline & & - & $(0.043)$ & $(0.054)$ \\
\hline Demographic Variables & $x$ & $x$ & $x$ & $x$ \\
\hline ADJ $R^{2}$ & 0.294 & 0.203 & 0.325 & 0.250 \\
\hline
\end{tabular}

Notes: ${ }^{*} p<0.10,{ }^{* *} p<0.05, * * * p<0.01$. Demograhic variable $\%$ foreign born Hispanics $(b=-0.002$ in final model $p<0.05)$

Table 4. 1st difference multivariate regression of suburban share poor (by income of suburb), 2000-2008 ( $N=100)$.

\begin{tabular}{|c|c|c|c|c|c|c|}
\hline & \multicolumn{2}{|c|}{ Low-Income } & \multicolumn{2}{|c|}{ Moderate-Income } & \multicolumn{2}{|c|}{ High-Income } \\
\hline & B & weighted & B & weighted & B & weighted \\
\hline \multirow[t]{2}{*}{ Intercept } & $-0.024 *$ & -0.016 & 0.015 & 0.006 & $0.032 * * *$ & $0.023 * * *$ \\
\hline & $(0.014)$ & $(0.012)$ & $(0.014)$ & $(0.013)$ & $(0.010)$ & $(0.008)$ \\
\hline$\Delta$ Suburb Total Pop Rate & $1.295^{* * *}$ & $1.314^{* * *}$ & $0.788 * * *$ & $0.617^{* * *}$ & $0.678 * * *$ & $0.712^{* * *}$ \\
\hline (applied within income group) & $(0.100)$ & $(0.111)$ & $(0.105)$ & $(0.102)$ & $(0.066)$ & $(0.061)$ \\
\hline$\Delta$ Suburb HCVRs Rate & $0.075^{* *}$ & $0.105^{* * *}$ & $0.099 * * *$ & $0.154^{* * *}$ & $0.096 * *$ & $0.083^{*} *$ \\
\hline (applied within income group) & $(0.035)$ & $(0.032)$ & $(0.034)$ & $(0.037)$ & $(0.038)$ & $(0.038)$ \\
\hline$\Delta$ Suburb 50\% FMR & 0.003 & -0.003 & $0.164^{* *}$ & $0.215^{* * *}$ & 0.019 & 0.036 \\
\hline (applied within income group) & $(0.060)$ & $(0.065)$ & (0.069) & $(0.075)$ & $(0.056)$ & $(0.059)$ \\
\hline \multirow[t]{2}{*}{$\Delta$ Job Sprawl } & $-0.184^{* *}$ & $-0.213^{* *}$ & 0.040 & -0.019 & $0.149 * *$ & 0.096 \\
\hline & $(0.089)$ & $(0.085)$ & (0.095) & $(0.091)$ & $(0.066)$ & $(0.060)$ \\
\hline \multirow[t]{2}{*}{$\Delta$ Black-White Segregation } & $0.099 *$ & $0.106^{*}$ & -0.009 & 0.001 & $-0.075^{*}$ & -0.061 \\
\hline & $(0.052)$ & $(0.057)$ & $(0.053)$ & $(0.058)$ & $(0.039)$ & $(0.040)$ \\
\hline Demographic Variables & $\mathrm{X}$ & $\mathrm{X}$ & $x$ & $\mathrm{X}$ & $x$ & $\mathrm{X}$ \\
\hline ADJ $R^{2}$ & 0.764 & 0.831 & 0.636 & 0.633 & 0.778 & 0.853 \\
\hline
\end{tabular}

Notes: ${ }^{*} p<0.10,{ }^{*} p<0.05, * * * p<0.01$; High-Income Model Demograhic variable \% foreign born Hispanics $(6=-0.001, p<0.05)$ and $\%$ college educated $(B=-0.004, p<0.05)$

Given the 2.3 percentage point increase in affordable housing in high-income suburbs, there was a greater expectation of a significant relationship between changes in affordable housing and suburban share poor changes. A rationale for this finding is that although there has been some growth in affordable housing in high-income suburbs, the overall supply at 17 percent of all affordable housing in the suburbs has not reached a critical amount that would specifically attract more poor residents.

How important are labor demand pulls on changes in the share of suburban poor? The macro level results indicate that the decentralization of jobs at the 3.5 (results not shown for these measures) and finally at the 10 miles radius outside of the CBD was not statistically significant. Up to this point, in the within suburb results presented in Table 4, there has not been great evidence that the suburbanization of poverty in any case is associated with changing labor demand toward the urban fringe. Results reveal that changes in job demand toward the urban fringe as measured by the degree to which jobs are decentralizing is associated with a slowing of the poor share in low-income suburbs over the period and an acceleration of the poor share in high-income suburbs (this result only significant in the unweighted result). That is, it does not appear that the poor are on average, following jobs to low-income suburbs but they appear to follow jobs to high-income suburbs. Others have found specific labor demand effects which suggest that White and Asian poor tend to live in suburbs at a higher rate when there are more suburban jobs available but a general population effect has not been observed (Howell \& Timberlake, 2014).

From the macro level results, it appears that residential segregation on average works to slow the share poor suburbanizing. Nevertheless, within suburb results reveal that while residential segregation levels may serve to slow suburbanization of the poor in high- 
income suburbs (significant for the unweighted result only) over the study period, segregation is actually associated with increases in the growth of the poor share in low-income suburbs (see Table 4). These results seem to suggest that while residential segregation seems to serve as a barrier for the entrance of the poor in high-income neighborhoods, it seems to serve as a welcome to the poor in low-income suburbs. Residential segregation embodies a complicated set of features within the metropolitan structure. As indicated earlier, various suburban neighborhoods have persistently applied measures such as exclusionary zoning to "preserve the character" of the neighborhood and, in part, the results presented here may reflect the likelihood that higher-income suburbs are still engaging in these practices.

To explore further the relationship between poverty suburbanization and residential segregation, all
100 metropolitan areas are examined to locate the 25 slowest and fastest poverty suburbanizing areas along with the largest increases and declines in segregation from 2000 to 2008. If there were no systematic relationships between these measures, one would expect 6.25 metropolitan areas to overlap in these indices. The equation used is as follows, $((100 / 25) \times(100 / 25)) \times$ $100=0.0625 \times 100=6.25$. Table 5 shows instead, that 12 out of the 25 areas with the slowest poverty suburbanization are also the areas with the highest increases in residential segregation. On the other end of the distribution, 12 of the 25 metro areas with the fastest poverty suburbanization are also the areas with the lowest increases in residential segregation. The observed relationship does not appear to be random. These results support multivariate findings showing a negative association between poverty suburbanization and residential segregation.

Table 5. Metropolitan areas with the slowest and fastest poverty suburbanization and highest increases and declines in residential segregation, 2000-2008.

\begin{tabular}{|c|c|c|c|c|c|}
\hline & & $\begin{array}{l}\text { Suburban Poor } \\
\text { Rate }\end{array}$ & Segregation & $\begin{array}{l}\text { Change in } \\
\text { Suburban Poor } \\
\text { Rate }\end{array}$ & $\begin{array}{l}\text { Change in } \\
\text { Segregation }\end{array}$ \\
\hline \multicolumn{6}{|c|}{ Slowest Poverty Suburbanization and Highest Segregation Increases } \\
\hline 1 & Allentown-Bethlehem-Easton, PA-NJ & 65.4 & 54.0 & -3.1 & 1.0 \\
\hline 2 & Springfield, MA Metro Area & 61.8 & 66.7 & -2.6 & 3.0 \\
\hline 3 & El Paso, TX & 17.8 & 37.3 & -1.2 & 1.0 \\
\hline 4 & McAllen-Edinburg-Mission, TX & 86.5 & 62.6 & -1.1 & 13.0 \\
\hline 5 & Albuquerque, NM & 40.0 & 43.2 & -0.9 & 11.0 \\
\hline 6 & Albany-Schenectady-Troy, NY & 74.0 & 63.7 & -0.2 & 3.0 \\
\hline 7 & Scranton-Wilkes-Barre, PA & 81.6 & 60.2 & -0.1 & 5.0 \\
\hline 8 & San Jose-Sunnyvale-Santa Clara, CA & 28.8 & 45.2 & 0.1 & 5.0 \\
\hline 9 & Bakersfield, CA & 66.9 & 54.7 & 0.3 & 2.0 \\
\hline 10 & San Antonio, TX & 23.3 & 51.2 & 0.6 & 1.0 \\
\hline 11 & Los Angeles-Long Beach-Santa Ana, CA & 51.2 & 69.9 & 1.0 & 2.0 \\
\hline 12 & Madison, WI & 33.4 & 51.6 & 1.1 & 5.0 \\
\hline \multicolumn{6}{|c|}{ Fastest Poverty Suburbanization and Highest Segregation Declines } \\
\hline 1 & New Orleans-Metairie-Kenner, LA & 58.6 & 63.5 & 13.9 & -6.0 \\
\hline 2 & Chicago-Naperville-Joliet, IL-IN-WI & 46.4 & 78.1 & 7.4 & -3.0 \\
\hline 3 & Richmond, VA & 65.5 & 53.2 & 5.9 & -4.0 \\
\hline 4 & Las Vegas-Paradise, NV & 67.8 & 38.8 & 5.6 & -5.0 \\
\hline 5 & Stockton, CA & 45.9 & 50.9 & 5.5 & -4.0 \\
\hline 6 & Lakeland-Winter Haven, FL & 82.6 & 41.4 & 5.1 & -14.0 \\
\hline 7 & $\begin{array}{l}\text { Little Rock-North Little Rock-Conway, } \\
\text { AR }\end{array}$ & 69.6 & 58.4 & 4.9 & -3.0 \\
\hline 8 & Houston-Sugar Land-Baytown, TX & 48.3 & 61.2 & 4.9 & -6.0 \\
\hline 9 & Cincinnati-Middletown, OH-KY-IN & 67.5 & 70.3 & 4.8 & -5.0 \\
\hline 10 & Kansas City, MO-KS & 48.6 & 65.8 & 4.7 & -3.0 \\
\hline 11 & New Haven-Milford, CT & 68.3 & 65.5 & 4.7 & -3.0 \\
\hline 12 & Akron, $\mathrm{OH}$ & 48.7 & 62.6 & 4.6 & -3.0 \\
\hline
\end{tabular}

Source: author's analysis of HUD data, Census 2000 and ACS five-year estimates 2005-2009. 


\section{Conclusions}

In this article factors associated with the suburbanization of poverty were examined. The analysis sought to address the overarching question: what metropolitan factors are associated with the suburbanization of the poor? In this paper, I looked to classic urban theories to explore the suburbanization of poverty within an urban change framework. The 2008 suburban poor share measures show uneven distribution of the poor across suburbs in the largest metropolitan areas in the U.S. However, increases in the poor share in suburbs indicate that suburbs once off limit to the poor are opening up, even in high-income suburbs. Several themes surface from a summary of results presented in this paper. First, broader population trends overwhelmingly help to explain growth in suburban poverty. Second, the heterogeneity of the suburb is crucial to understanding the suburbanization of poverty. Broadly, changes in housing affordability appear to be very important to changes in the spatial distribution of the poor and job decentralization has a more narrow effect (it works to pull and push the poor in specific circumstances). Generally, residential segregation acts as a barrier to the suburbanization of poverty. Each of these points is discussed in detail below.

The suburbanization of the poor appears to be connected to broader population decentralization trends. A dominant share of the metropolitan poor now residing in suburban locations is related to general population shifts to the suburbs. These trends are indicative of broader growth patterns in the U.S. "In the U.S., urban areas are growing and urban land area is expanding faster than urban population size, leading to a decline in average urban population density" (Marshall, 2007). Undoubtedly, the sifting and sorting of people across the metropolitan landscape is reflective of broader development patterns occurring in the metropolitan region. Various scholars have documented the process and consequences of sprawling development in detail (Jackson, 1985; Kneebone \& Berube, 2013). In general, where population growth is occurring is an important concern because of infrastructure requirements, environmental impacts, and demands placed on transportation systems to list a few. A related concern about the dominant share of the poor now residing in suburbs is their need for particular services. Transportation, social services, workforce development, and housing assistance services are important to encouraging and supporting the self sufficiency aspirations of families overall. The links between overall population shifts and shifts in the spatial distribution of the poor population requires further analysis to understand how to plan better for the growth patterns for the general population and the poor alike. It is also important to explore differences in the growth patterns based on the characteristics of suburban communities.

The heterogeneity of the suburbs is important towards understanding changes in the suburbanization of poverty. Within suburb effects displayed in Table 4 and Figure 4 show that the heterogeneity of the suburb is a necessary distinction when observing the association between changes in housing affordability, HCVRs, job decentralization, and residential segregation on changes in the suburban poor share. Unlike macro models presented in Table 3, changes in the spatial distribution of HCVRs as a poor subgroup in low, moderate, and high-income suburbs is associated differently with the spatial distribution of the poor in those suburbs. It appears that the greatest link between changes in the spatial distribution of HCVRS and the poor is in moderate-income suburbs, whereas these links are significant but weaker in high-income suburbs.

Equally interesting are the within suburb effects of housing affordability and the poor by the income of the suburb. The macro models displayed in Table 2 and 3 revealed a consistent significant relationship between housing affordability and the share of poor in suburbs. The macro models indicate an overall importance of changes in housing affordability and the spatial distribution of the poor. Results of the within suburb model extend the understanding of this relationship; changes in housing affordability in moderate-income suburbs in particular are linked to the spatial distribution of the poor in moderate-income suburbs. The relationship does not seem to be as important in low-income and high-income suburbs (see Table 4) suggesting that changes in housing affordability within middle-income suburbs may drive the observed relationship overall.

The paper sought to address the question: are jobs or housing more important to the suburbanization of the poor? Metropolitan wide changes in suburban housing affordability over the study period appear to more broadly affect the spatial distribution of the poor than job decentralization (see Table 3). The literature along with the current analysis indicates that growth rates in housing affordability are essential to poverty suburbanization. However, consideration of the heterogeneity present across suburbs in the largest metropolitan areas shows that albeit, no obvious connection in the macro model of job decentralization, there are important within suburb effects that demonstrate an existing relationship (see Table 4 and Figure 4). There is a countervailing relationship wherein job sprawl performs as a push factor in low-income neighborhoods and as expected may perform as a pull factor in highincome suburbs (this finding is only significant in the unweighted result). This finding supports the literature; various scholars have shown that the poor in particular follow jobs to shrink distance to job rich clusters on the urban fringe (see Covington (2009) for an extensive discussion). 
$\Delta$ Suburb Total Pop Rate (by income)

$\Delta$ Suburb HCVRs Rate (by income)

$\Delta$ Suburb $50 \%$ FMR (by income)

$\Delta$ Black - White Segregation

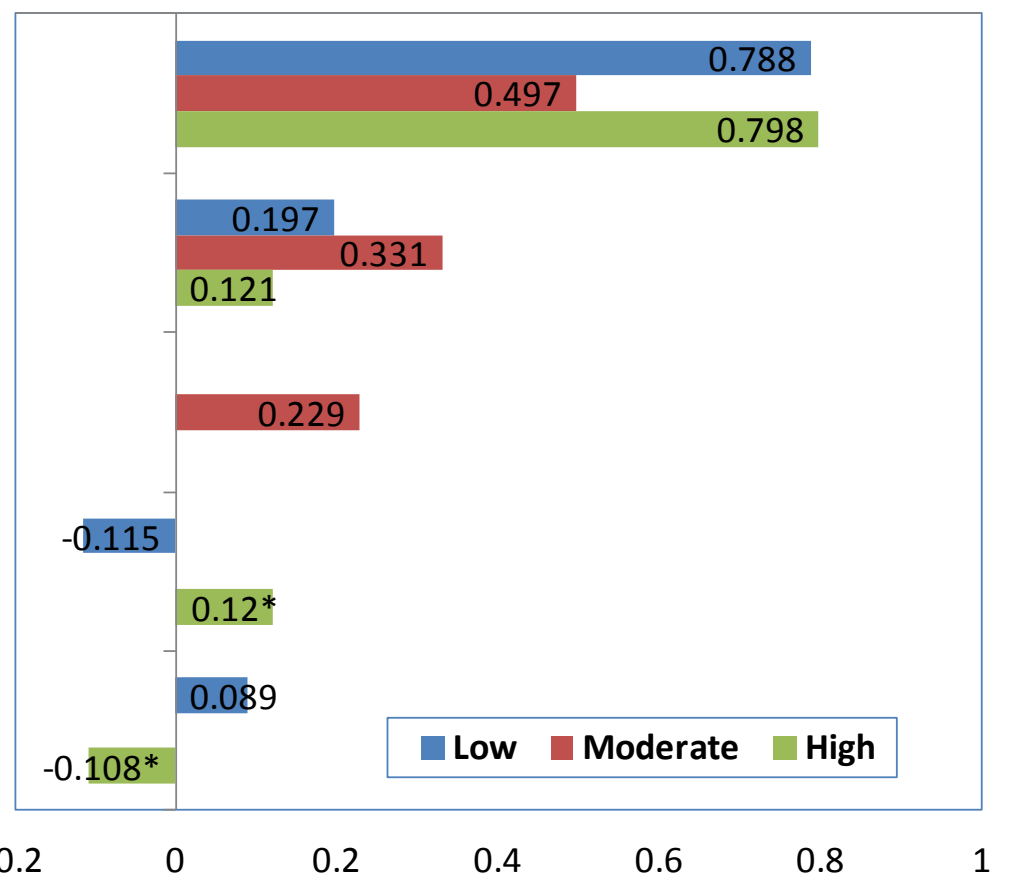

Figure 4. Key features within suburbs associated with poverty suburbanization, 2000-2008. Source: author's analysis of HUD data, Census 2000 and ACS five-year estimates 2005-2009. Significant Standardized coefficients (not displayed in tables above) are presented for the weighted change regressions. * Unweighted results.

Clearly, affordable housing opens up access to neighborhoods, and lack thereof, render suburban migration by the poor a less likely process. Despite the best efforts, there are strong views against affordable housing. There are many cases where affluent residents have vehemently fought the siting of affordable housing in upscale suburban neighborhoods (e.g., Mt. Laurel, NJ). Henri Lefevbre documented the role of real estate investments in the organization of metropolitan areas. The pattern of real estate development has the ability to shape neighborhoods, cities, suburbs and metropolitan areas. Often more lucrative real estate development projects which promise greater returns on investments are sought and more widely supported than affordable housing projects, especially in suburban communities. Local efforts to more equitably incorporate affordable housing options into local housing supply play a critical role in opening up suburbs, particularly in extending the poor's access to high-amenity suburbs.

Overall, findings show that the poor's inroads to high-amenity suburbs, including moderate and highincome suburbs, are associated with overall population growth, HCVRs, affordable housing and perhaps job sprawl and residential segregation (as displayed in Figure 4). Understanding those factors associated with suburban poor increases across neighborhood is essential to the reallocation of resources to neighborhoods most affected. Changes in the spatial distribution of the poor are associated strongly to changes in housing affordability in the suburbs. Perhaps this is related to growing rent pressures in expensive metropolitan housing markets (Glaeser, Kolko, et al., 2001, p. 4; U.S.
Census, 2003) which may be forcing low-income households in core urban locations to seek lower rent districts in the suburbs. This has great implications particularly for housing authorities within large metropolitan areas. As a result, it is important for housing authorities to reconsider how these changes might prompt administrators to realign services and resources.

Generally, residential segregation acts as a barrier to the suburbanization of poverty. Despite significant increases in poverty suburbanization, residential segregation, in part, a byproduct of real estate development decisions, information asymmetry, preferences, and racial discrimination appear to slow poverty suburbanization. The lesson remains that there are powerful forces including political, economic and social that aid particular individuals, and organizations in shaping the urban landscape in ways that continue to work in their favor. Despite, recent increases in suburban share poor in high-amenity suburbs, residential segregation in high-income suburbs appears to be a push factor which may slow additional poor from suburbanizing within higher-amenity suburbs. Other evidence shows some selection of the poor entering high-amenity suburbs, both findings from Howell and Timberlake (2014) and from Covington, Freeman and Stoll (2011) showed that White poor families and White HCVRs more disproportionately represent the share of the poor in highincome suburbs. These findings perhaps are revealing that longstanding barriers associated with the exclusionary practices of the poor more generally and to minority households in particular may remain. In alignment with Henri Lefevbre, the distinction between 
effects in low versus high-income suburbs is potentially the protection of capital. As with the efforts of NAREB in the 1920s, there remain interests to keep highamenity neighborhoods relatively homogenous.

As a final point, it would appear that the same barriers that exist in high-amenity suburbs do not exist in low-amenity suburbs. Residential segregation in lowincome suburbs appears to act as a pull factor for the poor. The swell of suburban poor is undeniable. Many of the challenges associated with central city poverty (e.g., an eroding tax base, poor performing schools) will now be suburban challenges too; take for example the recent administrative reaction to citizenry enraged by a police shooting and murder in Ferguson. Ferguson is a low-income suburb that over the last three decades increased substantially the share of poor that reside in the community (Kneebone, 2014). Ferguson is struggling with changing social dynamics and other neighborhoods that have changed as dramatically are likely confronting similar challenges. Whether or not suburban jurisdictions will fare better than central cities in handling their poorer populations is an important question deserving of further research.

\section{Acknowledgements}

The research presented in this paper has been inspired by the great work completed by Elizabeth Kneebone and Alan Berube at the Brookings Institution. Their body of work has stimulated a series of important questions and their comments on an early paper on the suburbanization of HCVR lead to my current work. I am also deeply indebted to friends and colleagues Lance Freeman at Columbia and Michael Stoll at the University of California, Los Angeles for providing critical comments on early drafts of the article. My Research Assistant, Diana Benitez, made an important contribution to the background research and formatting of the paper. I deeply appreciate reviewers' and Editor's remarks on early drafts of the paper and the invitation to complete my manuscript for the housing special issue. However, I take sole responsibility for any errors.

\section{Conflict of Interests}

The author declares no conflict of interest.

\section{References}

Alonso, W. (1964). Location and Land Use: Toward a general theory of land rent. Cambridge University Press.

Baer, W. C., \& Williamson, C. B. (1988). The filtering of households and housing units. Journal of Planning Literature, 3(2), 127-152.

Barron, B., \& Barron, E. (1965). The Inhumanity of Urban Renewal. Arlington, VA: Crestwood Books.

Berube, A., \& Kneebone, E. (2006). Two Steps Back:
City and Suburban Poverty Trends 1999-2005. Washington, DC: Brookings Institution.

Bocian, D. G., Smith, P., Green, G., \& Leonard, P. (2010). Dreams Deferred: Impacts and Characteristics of the California Foreclosure Crisis. Durham, NC: Center for Responsible Lending.

Bravve, E., Bolton, M., Couch, L., \& Crowley, S. (2012). Out of Reach 2012. Washington, D.C: The National Low Income Housing Coalition.

Bullard, R., Johnson, G., \& Torres, A. (2000). Sprawl city: Race, politics and planning in Atlanta. Island Press.

Burgess, E. W. (1925). The growth of the city: An introduction to a research project. American Sociological Society, 18, 85-97.

Cherry, R. D., \& Rodgers, W. M. (Eds.) (2000). Prosperity for All? The Economic Boom and African Americans. New York: Russell Sage Foundation.

Chudacoff, H. P., Smith, J.E., \& Baldwin, P. C. (2010). The Evolution of American Society (7th ed.). Upper Saddle River, NJ: Pearson.

Cochran, C. L., \& Malone, E. F. (2010). Public Policy Perspectives and Choices (4th ed.). Boulder, CO: Rienner Publishers, Inc.

Covington, K. L. (2009). Spatial mismatch of the poor: An explanation of recent declines in job isolation. Journal of Urban Affairs, 31(5), 559-587.

Covington, K., Freeman, L., \& Stoll, M. (2011). The Suburbanization of Housing Choice Voucher Recipients. Washington, DC: Brookings Institution.

de Souza Briggs, X. (1998). Brown kids in white suburbs: Housing mobility and the many faces of social capital. Housing policy debate, 9(1), 177-221.

Department of Housing and Urban Development (HUD). (2011). Worst Case Housing Needs 2009: A Report to Congress. Washington, DC.

Department of Housing and Urban Development (HUD). (2013). FY 2013 Fair Market Rent Documentation System. Washington, DC. Retrieved from http://www.huduser.org/portal/datasets/fmr/fmrs /fy2013_code/2013summary.odn?INPUTNAME=ME TRO31100MM4480*Los+Angeles+County\%2B0603 799999\&data $=2013 \&$ year $=2013 \& \mathrm{fmrtype}=\% 24 \mathrm{fmrt}$ ype\%24\&incpath=C:\%5CHUDUSER\%5CwwwMain\% 5Cdatasets\%5Cfmr\%5Cfmrs\%5CFY2013_Code\&sele ction_type $=$ county \&path $=\% 24$ path $\% 24 \&$ stname $=C$ alifornia

Department of Housing and Urban Development (HUD). (2014). Neighborhood Stabilization Grant Program. Washington, DC. Retrieved from http://portal.hud.gov/hudportal/HUD?src=/progra m_offices/comm_planning/communitydevelopmen t/programs/neighborhoodspg

Farley, R., \& Frey, W. H. (1994). Changes in the segregation of whites from blacks during the 1980s: Small steps toward a more integrated society. American Sociological Review, 59(1), 23-45.

Freeman, R. B. (2001). The Rising Tide Lifts...? (No. 
w8155). Cambridge, MA: National Bureau of Economic Research.

Frey, W. H., \& Geverdt, D. (1998). Changing Suburban Demographics, Beyond the "Black-While, CitySuburb" Typology (Report No, 98-422). Michigan: Population Studies Centre, University of Michigan.

Frey, W., Berube, A., Singer, A., \& Wilson, J. (2009). Getting Current: Recent Trends in Metropolitan America. Washington, DC: Brookings Institution.

Giuliano, G. (1989), Research policy and review 27. New directions for understanding transportation and land use. Environment and Planning A, 21(2), 145-159.

Glaeser, E. L., \& Kahn, M. E. (2001). Decentralized Employment and the Transformation of the American City (No. w8117). Washington, DC: National Bureau of Economic Research.

Glaeser, E. L., \& Vigdor, J. L. (2001). Racial Segregation in the Census 2000: Promising News. Washington, DC: Brookings Institution, Center on Urban \& Metropolitan Policy.

Glaeser, E. L., Kahn, M. E., \& Chu, C. (2001). Job Sprawl: Employment Location in US Metropolitan Areas. Washington, DC: Brookings Institution, Center on Urban and Metropolitan Policy.

Glaeser, E. L. (2008). Cities, Agglomeration and Spatial Equilibrium. New York: Oxford University Press.

Glaeser, E. L., Kolko, J., \& Saiz, A. (2001). Consumer city. Journal of Economic Geography, 1(1), 27-50.

Goering, J. M., Kraft, J., Feins, J., McInnis, D., Holin, M. J., \& Elhassan, H. (1999). Moving to Opportunity for Fair Housing Demonstration Program: Current Status and Initial Findings (Accession \#8771). Washington, D.C.: HUDUSER.

Gotham, K. F. (2000). Urban space, restrictive covenants and the origins of racial residential segregation in a US city, 1900-50. International Journal of Urban and Regional Research, 24(3), 616-633.

Gotham, K. F. (2002). Race, Real Estate, and Uneven Development: The Kansas City Experience, 1900-2000. New York, NY: SUNY Press.

Hanlon, B., Short, J. R., \& Vicino, T. (2010). Cities and Suburbs. New Metropolitan Realities in the U.S. New York, NY: Routledge.

Haughey, R. M. (2001). Urban Infill Housing: Myth and Fact. Washington, DC: Urban Land Institute.

Heinlich, R., \& Anderson, W. (2001). Development at the Urban Fringe and Beyond: Impacts on Agriculture and Rural Land. ERS Agriculture Economics (Report no. 803). Washington, DC: U.S. Department of Agriculture.

Helper, R. (1969). Racial Policies and Practices of Real Estate Brokers. Minneapolis, MN: University of Minnesota Press.

Hines Jr, J. R., Hoynes, H. W., \& Krueger, A. B. (2001). Another Look at whether a Rising Tide Lifts All Boats (No. w8412). Washington, DC: National Bureau of Economic Research.

Holzer, H. J., Raphael, S., \& Stoll, M. A. (2006). Employ- ers in the boom: How did the hiring of less-skilled workers change during the 1990s? The Review of Economics and Statistics, 88(2), 283-299.

Howell, A. J., \& Timberlake, J. M. (2014). Racial and ethnic trends in the suburbanization of poverty in US metropolitan areas, 1980-2010. Journal of Urban Affairs, 36(1), 79-98.

Immergluck, D. (2012). Distressed and dumped: Market dynamics of low-value, foreclosed properties during the advent of the federal neighborhood stabilization program. Journal of Planning Education and Research, 32(1), 48-61.

Jackson, K. T. (1985). Crabgrass Frontier: The Suburbanization of the United States. London, England: Oxford University Press.

Jacobs, J. (1961). The Death and Life of Great American Cities. New York City: Random House.

Jargowsky, P. (2003). Stunning Progress, Hidden Problems. Washington, DC: Brookings Institution.

Kennedy, M., \& Leonard, P. (2001). Dealing with Neighborhood Change: A Primer on Gentrification and Policy Choices. Washington, DC: The Brookings Institution.

Kneebone, E. (2009). Job Sprawl Revisited: The Changing Geography of Metropolitan Employment. Washington, DC: Brookings Institution, Metropolitan Policy Program.

Kneebone, E. (2014). Ferguson, Mo. Emblematic of Growing Suburban Poverty. The Avenue: Rethinking Metropolitan America (August 15, 2014). Washington, D.C.: Brookings Institution.

Kneebone, E., \& Berube, A. (2013). Confronting Suburban Poverty in America. Washington, DC: Brookings Institution Press.

Kneebone, E., \& Garr, E. (2010). The suburbanization of poverty: Trends in metropolitan America, 2000 to 2008. Metropolitan Policy Program. Washington, DC: Brookings Institution.

Krueger, A. B., \& Solow, R. M. (Eds.). (2001). The Roaring Nineties: Can Full Employment be Sustained? New York, NY: Russell Sage Foundation.

Lee, S., \& Leigh, N. G. (2007). Intrametropolitan spatial differentiation and decline of inner-ring suburbs: A comparison of four U.S. metropolitan areas. Journal of Planning Education and Research, 27(2), 146-164.

Lee-Chuvala, C. (2012). Upward Mobility? Classifying Suburban Poverty. APPAM Fall Research Conference. Baltimore, MD.

Lefebvre, H. (1994). The Production of Space. Malden, MA: Blackwell Publishers.

Levy, J. M. (2013). Contemporary Urban Planning. Upper Saddle River, NJ: Pearson/Prentice Hall.

Lopez, R., \& Hynes, H. P. (2003). Sprawl in the 1990s: Measurement, distribution, and trends. Urban Affairs Review, 38(3), 325-355.

Lowry, I. S. (1960). Filtering and housing standards: A conceptual analysis. Land Economics, 362-370. 
Lucy, W. H., \& Phillips, D. L. (2000). Confronting Suburban Decline: Strategic Planning for Metropolitan renewal. Washington, D.C.: Island Press.

Marshall, J. D. (2007). Urban land area and population growth: A new scaling relationship for metropolitan expansion. Urban Studies, 44(10), 1889-1904.

Martin, R. W. (2001). The adjustment of black residents to metropolitan employment shifts: How persistent is spatial mismatch? Journal of Urban Economics, 50(1), 52-76.

Massey, D. S., \& Denton, N. A. (1993). American Apartheid: Segregation and the Making of the Underclass. Cambridge, MA: Harvard University Press.

Macionis, J. J., \& Parrillo, V. N. (2013). Cities and Urban Life (6th ed.). Upper Saddle River, NJ: Pearson.

McGirr, L. (2012). The new suburban poverty. New York Times. Retrieved from http://campaignstops.blogs. nytimes.com/2012/03/19/the-new-suburbanpoverty/?_php=true\&_type=blogs\&_r=0

Mikelbank, B. A. A. (2004). Typology of U.S. suburban places. Housing Policy Debate, 15(4), 935-964.

Mink, G., \& O'Connor, A. (Eds.). (2004). Poverty in the United States: An Encyclopedia of History, Politics, and Policy (Vol. 2). Santa Barbara, CA: Abc-Clio.

Mishel, L., Bivens, J., Gould, E., \& Shierholz, H. (2002). The State of Working America. Ithaca, NY: Cornell University Press.

Palen, J. J. (1995). The Suburbs. New York: McGraw-Hill.

Partridge, M. D., \& Rickman, D. S. (2008). Does a rising tide lift all metropolitan boats? Assessing poverty dynamics by metropolitan size and county type. Growth and Change, 39(2), 283-312.

Pattillo, M. (2005). Black middle-class neighborhoods. Annual Review of Sociology, 31, 305-329.

Pfeiffer, D. (2012). African Americans' search for "more for less" and "peace of mind" on the exurban frontier. Urban Geography, 33(1), 64-90.

Pogodzinski, J. M. (1991). The effects of fiscal and exclusionary zoning in household location: A critical review. Journal of Housing Research, 2(2), 145-160.

Puentes, R., \& Orfield, M. (2002). Valuing America's First Suburbs: A Policy Agenda for Older Suburbs in the Midwest. Metropolitan Policy Program Report. Washington, DC: Brookings Institution.

Puentes, R., \& Warren, D. (2006). One-fifth of America:
A Comprehensive Guide to America's First Suburbs. Metropolitan Policy Program. Washington, DC: The Brookings Institution

Raphael, S., \& Stoll, M. A. (2002). Modest Progress: The Narrowing Spatial Mismatch between Blacks and Jobs in the 1990s. Washington, DC: The Brookings Institution.

Raphael, S., \& Stoll, M. A. (2010). Job Sprawl and the Suburbanization of Poverty. Metropolitan Policy Program. Washington, DC: The Brookings Institution.

Roback, J. (1982). Wages, rents, and the quality of life. Journal of Political Economy, 90(6), 1257-1278.

Schildt, C., Cytron, N., Kneebone, E., \& Reid, C. (2013). The Subprime Crisis in Suburbia: Exploring the Links between Foreclosures and Suburban Poverty. San Francisco, CA: Federal Reserve Bank of San Francisco.

Schwartz, A. F. (2013). Housing Policy in the United States. London: Routledge.

Smetanka, M. J. (2011). Foreclosure scourge hitting the suburbs. Star Tribune. Retrieved from http:// www.startribune.com/local/south/16881311.html

Sohmer, R. R., \& Lang, R. E. (2001). Downtown Rebound. Washington, DC: FannieMae Foundation and The Brookings Institution.

South, S. J., \& Crowder, K. D. (1997). Residential mobility between cities and suburbs: Race, suburbanization, and back-to-the-city moves. Demography, 34(4), 525-538.

Stoll, M. A. (2006). Job sprawl, spatial mismatch, and black employment disadvantage. Journal of Policy Analysis and Management, 25(4), 827-854.

U.S. Census (2003). Housing Cost of Renters: 2000. C2KBR21, Census Brief. Washington, DC: U.S. Census Bureau.

U.S. Commission on Civil Rights. (1973). Understanding fair housing (Clearinghouse Publication 42, February 1973). Washington, DC. U.S. Commission on Civil Rights. Retrieved from http://www.law.umary land.edu/marshall/usccr/documents/cr11042.pdf

Wilson, W.J. (1987). The Truly Disadvantaged: The Inner City, the Underclass, and Public Policy. Chicago, IL: University of Chicago Press.

WoTapka, D. (2010). Housing bust opens new doors for subsidized tenants. Wall Street Journal. Retrieved from http://sweetness-light.com/archive/foreclo sures-mean-luxury-section-8-houses

\section{About the Author}

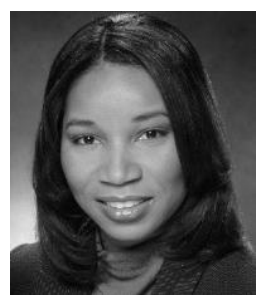

\section{Dr. Kenya L. Covington}

Kenya L. Covington, Ph.D. conducts empirical research that examines causes of social and economic inequality associated with the structural makeup of metropolitan areas. Often her work suggests ways to better utilize social and urban policies that can mitigate disparities in economic opportunity and well-being overall. She is a graduate of the University of Maryland, M.C.P. from College Park and Ph.D. from UMBC. Over her career, Dr. Covington's articles have appeared in the Journal of Urban Studies, Brookings Institution Policy Briefs, Journal of Urban Affairs, and many others. 